\title{
The occurrence of boring bivalve (Genus: Zachsia), in a tropical seagrass meadow in Gaya Island (Sabah, Malaysia) and its possible ecological implications
}

\author{
Tzuen-Kiat Yap ${ }^{1 *}$, John Barry Gallagher ${ }^{1},{ }^{3}$, Ejria Saleh $^{\mathbf{1}}$ and Vienna Anastasia Admodisastro ${ }^{2}$ \\ ${ }^{1}$ Borneo Marine Research Institute, Universiti Malaysia Sabah, 88400 Kota Kinabalu, Sabah, Malaysia \\ ${ }^{2}$ Marine Ecology Research Centre, 88400 Kota Kinabalu, Sabah, Malaysia \\ ${ }^{3}$ Centre for Marine and Coastal Studies, Universiti Sains Malaysia, 11800 Penang, Malaysia
}

*Corresponding author: mic_yap05@hotmail.com

\begin{abstract}
Shipworms (family Teredinidae) are specialized bivalves that bore into the submerged wooden structures and mangrove trees, except genus Zachsia which is associated with seagrass rhizome. However, only one species has been described, located in Russian, Korean and Japanese waters and associated only with genera Phyllospadix and Zostera. Potentially wider distributions and even new species within this group have not been reported from another bioregion. Given the potential impacts on seagrass health, it is important to ascertain if the distribution of Zachsia extends across other climatic regions and seagrass species. In response, a study was conducted in a seagrass meadow at Gaya Island (Sabah, Malaysia). A total of 900 seagrass shoots were randomly excavated from a mixed seagrass bed of Enhalus acoroides, Cymodocea rotundata and C. serrulata. It was found that Zachsia sp. was present within the rhizomes of E. acoroides and C. rotundata, with an occupancy of around $12 \%$ occupancy $(\mathrm{n}=100)$ and $1 \%(\mathrm{n}=400)$, respectively. A post-mortem examination indicated that the bivalve appeared to have ingested most of the rhizome's internal tissues, leaving behind a calcareous hollow tube. Furthermore, this apparent infestation appeared to significantly reduce shoot growth by around $70 \%$ from $0.738 \pm 0.036$ to $0.220 \pm 0.038 \mathrm{~cm}^{\text {day }}{ }^{-1}$. This finding may be significant, as it suggests, for the first time, that the rhizome parasitism is another possible vector in controlling seagrass growth and mortality. Further investigations are required to determine if this boring bivalve is indeed a new species, its distribution in other tropical areas and its role in the ecosystem.
\end{abstract}

Keywords: Parasitism, Teredinidae, Zachsia, Boring bivalve, Tropical seagrass

\section{Introduction}

Seagrass is the only flowering plant (angiosperm) that has evolved to fully adapt to the marine environment (Orth et al., 2000; Bujang et al., 2006). The plant structure consists of leafy shoots anchored to the bottom by a network of rhizomes and roots. Rhizome plays important roles as nutrient storage (Terrados et al., 1999) and clonal vegetative expansion. The attached roots are used for nutrient absorption within 10 to $30 \mathrm{~cm}$ of the sediment (Duarte et al., 1998).

Seagrass meadows are important globally, regionally and locally. They contribute to carbon sequestration, with current estimates of around $15 \%$ of the oceans annual carbon storage capacity (Duarte, 2002; Duarte et al., 2013). Over regional scales, seagrass meadows export organic carbon to adjacent ecosystems, maintain the clarity of the water by stabilizing sediments, play a role in coastal protection, and protect more vulnerable coral ecosystems by trapping nutrients and organic detritus from coastal eutrophication supply and land erosion (Duarte, 2002). At the local level, seagrass meadows are areas with high biodiversity for both invertebrate and vertebrate fisheries. This provides a food source to the local communities, and the endangered species, dugongs, and turtles (Burkholder et al., 2013).
Unfortunately, there appears to a worldwide decline of seagrass meadow coverage (Short et al., 2007). To date, the major focus on the reasons for seagrass declines has been on the more visible effects of direct and indirect human activities. Direct activities include mechanical damage, reduction in light and nutrient eutrophication. Mechanical damage resulting ostensibly from dredging, destructive fishing methods (i.e., trawling and fish bombing) and anchoring (Bujang et al., 2006). Reduction in light is caused by sediment run-off from changes in land use and coastal development, and nutrient eutrophication. Indirect effects include climate change (increasing sea water level and temperature, and frequent storms), and loss of resilience that lead to disease outbreak (Duarte, 2002).

However, the less visible effects, such as root and rhizome parasitism, a phenomenon common to terrestrial plants (see Thrower and Chan, 1980; Marvier 1998; Wondafrash et al., 2013), has been largely ignored. Instead, seagrass shoot and rhizome borers have been confined to a detritivore niche occupied by polychaetes, nematodes, and isopods (Guidetti et al., 1997; Guidetti, 2000; Cookson and Lorenti, 2001). A possible exception is the reported presence of a boring bivalve. The boring bivalves normally known as shipworms, are well-known for their capability to cause massive damage to wooden structures. 
Zachsia is the only genus that had been reported to bore into seagrass rhizome, and there is only one representative species, Zachsia zenkewitschi (Bulatoff and Rjabtschikoff, 1933). However, it has only been described, located in Russian and Japanese waters (Turner et al., 1983; Haga, 2006; Xu and Zhang, 2012). There have been other possible sightings of new species in Madagascar (Turner and Yakovlev, 1983), Vietnam and Papua New Guinea (Shipway et al., 2016), but their extent and association were not formally described. Consequently, its presence across other seagrasses and climatic regions still largely unknown, but nevertheless it may still have a wider global distribution.

To test the above contention, a pilot study was conducted at Gaya Island, one of the islands in Tunku Abdul Rahman Marine Park, Sabah (Malaysia). The meadows host 11 of 12 species of seagrasses that are found within Sabah waters, giving a sufficient diversity in likely niches for the possible presence and abundance of Zachsia. The objectives of this study are 1) to investigate the presence of Zachsia within the rhizomes of the tropical seagrass species, Enhalus acoroides, Cymodocea rotundata and Cymodocea serrulata; and 2) to characterize its morphology and occupancy within the rhizome, as behaviour consistent with possible parasitism.

\section{Methods}

The study was conducted, between June and September 2016. It is important to note that any damage from the sampling was offset by a seagrass transplantation program. The seagrass beds located at the west coast of Gaya Island $6^{\circ} 00^{\prime} 33.94^{\prime \prime} \mathrm{N}, 116^{\circ} 03^{\prime} 49.58^{\prime \prime} \mathrm{E}$ (Figure 1), formed from single or mixed species, adjacent to the stilt houses with less than 1.5 metre water depth. Three tropical seagrass species, $E$. acoroides, $C$. serrulata and $C$. rotundata were targeted for this assessment.

Collections of the shoot and rhizome were taken by shovelling $100 \mathrm{~cm}^{2}$ clods from targeted seagrass meadows. A number of clods were randomly dug up and total excavation did not exceed $20 \%$ of the total bed area to allow for recovery. Sediment was immediately rinsed from the seagrass rhizome and root structure kept submerged in a container of local seawater to reduce desiccation, and covered with a garden net to prevent heat damage. All the collected seagrass samples were then transported to the Marine Ecology Research Centre, MERC (Figure 1) for sorting, counting, and identification. Each individual shoot and rhizome were counted (total of 100 E. acoroides and 400 shoots of $C$. rotundata and $C$. serrulata each) were then carefully examined for the presence of Zachsia in MERC, that is, an emerging calcareous tube from leaf meristem point, and borrowing tube with white calcareous lining inside of the rhizome with the remains of transparent worm-like organisms. A total number of individuals of Zachsia was counted and their body length was recorded. Although, it should be noted that the boring bivalve may have originally occupied the other end part of the uncollected rhizome, or else it could have died and lost. Empty calcareous tubes inside the rhizome were taken as past occupancy and were not presented in this study. Damaged and dead specimens were preserved in absolute ethanol for species identification and future studies.

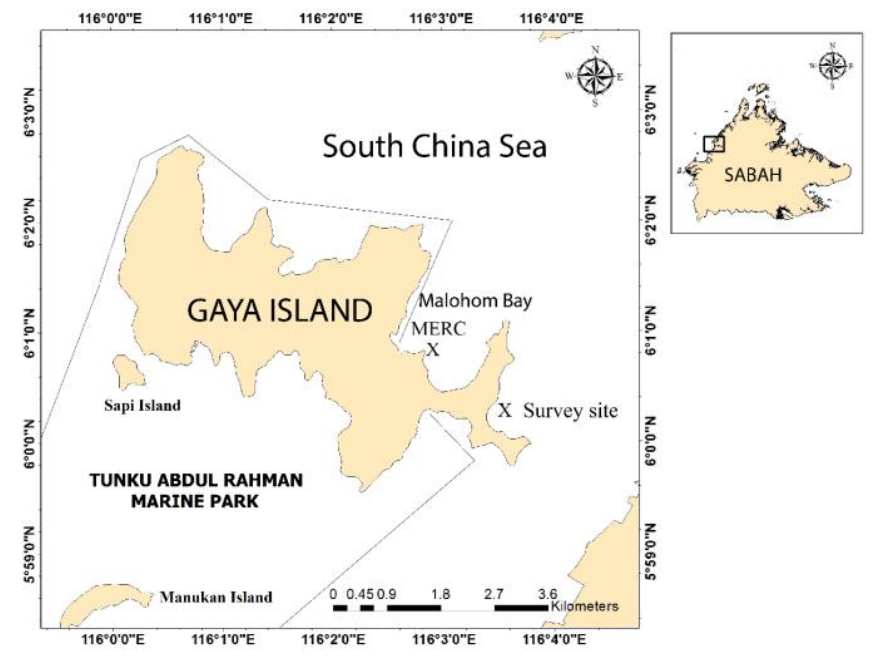

Figure 1. Seagrass collection was conducted from JuneSeptember 2016 on the west coast of Gaya Island, where seagrass meadows existed adjacent to human settlement (study site). Preserved specimens were deposited at Borneo Marine Research Institute, Universiti Malaysia Sabah (IPMBM Teredinidae-Zachsia-001).

The effects of Zachsia on current rhizome occupancy were tested by their impact on seagrass shoot growth rates from 26 June - 17 July 2016. Healthy and infested Enhalus seagrass were transplanted into two tanks, each measuring $1.6 \mathrm{~m} \times 1.3 \mathrm{~m} \times 0.5 \mathrm{~m}$, and connected to filtered seawater supply and exposed to sunlight that passed through transparent polycarbonate roof. A total of 14 survived $E$. acoroides shoots were randomly selected after transplantation into the tank. One infested shoot and one free of infection but sharing the same rhizome were measured to determine growth rate. Leaf length from meristem point to the tip of the leaf was weekly measured and recorded to determine the growth rate. All the leaves included new leaf formations in the shoots and were measured weekly. Damaged leaves were not measured for that particular week onward. Unfortunately, the infested shoot died on 22 July 2016 and no further result could be obtained. Data on growth rate was tested for normality before further statistical processing through t-test using the PAST version 3.15.

Identification of Zachsia was based on the form of calcareous structure. Pallet and shell valves were observed under a scanning electron microscope (SEM, Carl Zeiss MA10). However, morphology and identification of the Zachsia were limited to the pallet of preserved specimens, which were examined under compound microscope $4 \mathrm{X}$ and SEM. According to Turner (1966), as reviewed by Voight (2015), the pallet is the main identification key for boring bivalve (Teredinidae), since shell valve morphologies can be different within species. 


\section{Results}

\section{Number of shoot occupancy}

A total of 16 specimens of Zachsia were collected during the study period. Their bodies were transparent and vermiform (Figure 2). Internal organ including gills and digestive tract, a pair of shell valves (anterior), a pair of siphon and pallets (posterior) were visible. Body length excluding siphon measured $0.8-9.5 \mathrm{~cm}$. Twelve individuals were found in the rhizomes of the seagrass, $E$. acoroides, four in $C$. rotundata and none in $C$. serrulata (Table 1 ). The total occupancy was $12 \%$ and $1 \%$ for $E$. acoroides and C. rotundata, respectively.

Table 1. Total number individuals and occupancy percentage of Zachsia found in the 3 seagrass species, Enhalus acoroides, Cymodocea serrulata and C. rotundata.

\begin{tabular}{lccc}
\hline $\begin{array}{l}\text { Seagrass } \\
\text { species }\end{array}$ & $\begin{array}{c}\text { Number of } \\
\text { seagrass } \\
\text { shoots }\end{array}$ & $\begin{array}{c}\text { Number of } \\
\text { individual }\end{array}$ & $\begin{array}{c}\text { Occupancy } \\
\text { percentage } \\
(\%)\end{array}$ \\
\hline $\begin{array}{l}\text { Enhalus } \\
\text { acoroides }\end{array}$ & 100 & 12 & 12 \\
$\begin{array}{l}\text { Cymodocea } \\
\text { serrulata } \\
\begin{array}{l}\text { Cymodocea } \\
\text { rotundata }\end{array}\end{array}$ & 400 & 0 & 0 \\
\hline
\end{tabular}

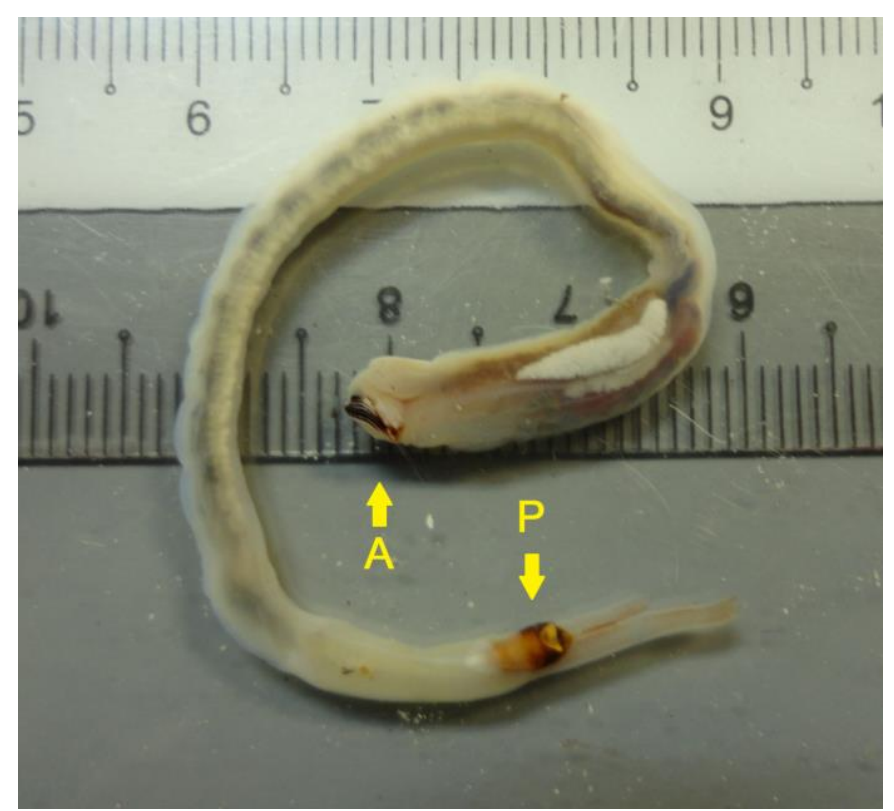

Figure 2. A representative specimen of seagrass boring bivalve extracted from the rhizome of Enhalus acoroides. It has almost transparent body that reveals the internal organs, including gills and digestive tract. A pair of shell valves (A) is located at the anterior side. Pallet $(\mathrm{P})$ with a pair of siphons located at the posterior end of the animal.

\section{Calcareous structures}

The calcareous structure was divided into two parts, a relatively robust calcareous tube which was seen rising from the plant meristem point up to $8 \mathrm{~cm}$ in length, and a more delicate calcareous lining tube, more than $15 \mathrm{~cm}$ in length that formed inside the rhizome itself. Interestingly, in many cases (10 of the 16 samples for both seagrass species), the calcareous tubes emerging from the rhizome were encapsulated inside living leaf tissue (Figure 3), with a surface opening. The opening could allow the siphon to extend into the water column, presumably for ventilation and waste excretion. It was also noted in two cases that two similar size individuals and their calcareous tubes emerged from the same Enhalus shoot (Figure 3). In addition, an exposed Zachsia from a $C$. rotundata rhizome, where the calcareous tube was snapped away accidentally, was rebuilt over 2 days (Figure 5).

In the larger Enhalus rhizome (diameter of approximately $1.5 \mathrm{~cm}$ ), it was found that up to four calcareous lining tubes occupied most of the space by twisting around each other (Figure 3). Furthermore, laboratory observations on $C$. rotundata indicated that the Zachsia bored in from the top of the leaf meristem and migrated through the vertical stem and into the rhizome. However, it was also observed that the calcareous lining tube had extended beyond the collected rhizome more than $15 \mathrm{~cm}$, which had been cut during excavation.

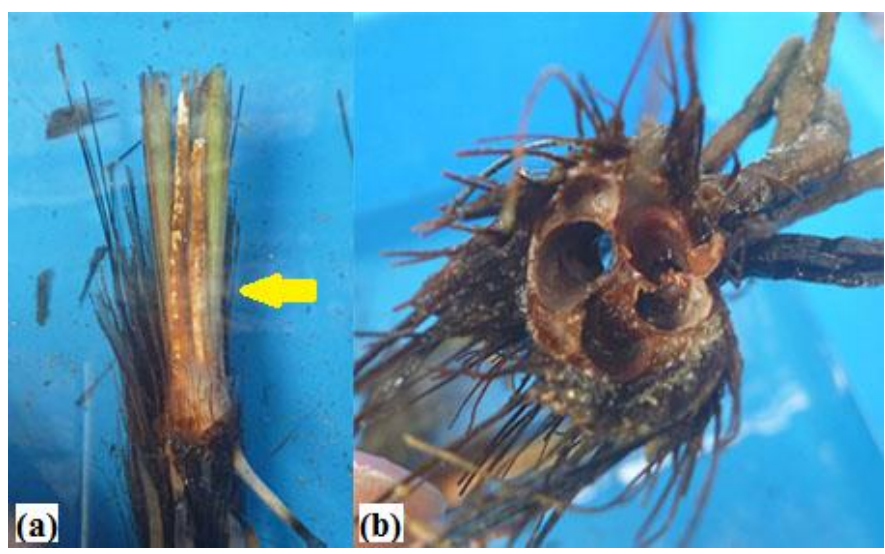

Figure 3 (a). Two Zachsia calcareous tubes emerged from rhizome next to each other in the same Enhalus shoot and were formed inside the leaf tissue (Lateral view) (b) Enhalus rhizome with a diameter $1.5 \mathrm{~cm}$ is occupied by 4 boring tunnels (Dorsal or cross-section view).

\section{Pallet and shell morphology}

The pallet is a calcareous structure used to seal the tube opening during disturbance or unfavourable environment, while a pair of shells is adapted for the boring function instead of protection. The shape of the pallets was narrower and longer, with blade length measuring 1-4 mm. The stalk holding the pallet blade with the animal's tissue is short, straight, translucent and rounded at its distal end. Other observations found yellow colouration in smaller pallet and reddish brown in the larger pallet. Both the images from the compound and SEM (Figure 4) show a thumbnail depression and a hollow cavity inside the pallet. Only the SEM image revealed rows of toothed ridges on the part of the shell valves that are used to drill into the rhizome tissues (Figures 5 and 6). 


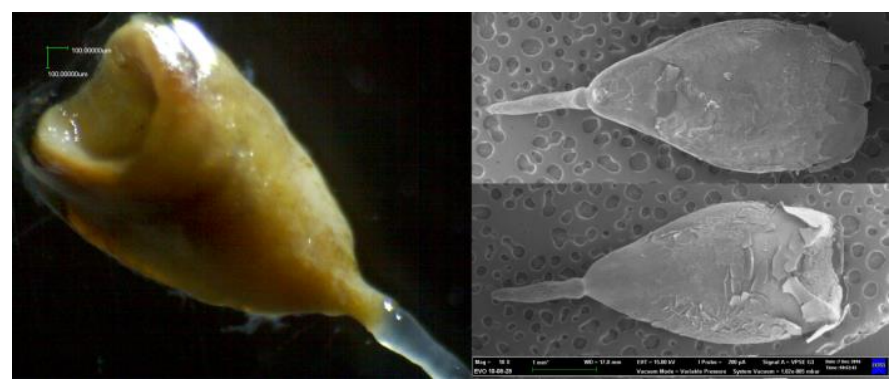

Figure 4. Pallet of about $4 \mathrm{~mm}$ (blade length) under a compound light microscope 40X (left) and Scanning Electron Microscope 18X (right). The pallet is narrow and elongated, with a thumbnail depression caused by a U-shape concavity.

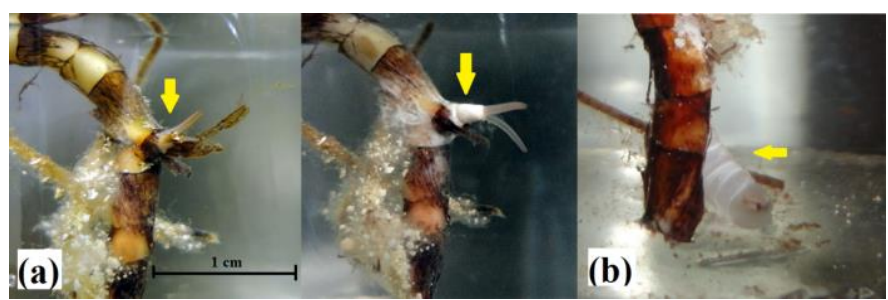

Figure 5 (a). Posterior part of living Zachsia, a pair of siphon and pallet (yellow arrow) were exposed from $C$. rotundata rhizome. A new whitish calcareous tube (yellow arrow in middle photo) was re-built after 2 days. (b) New whitish calcareous lining tube (yellow arrow) is extended outside $C$. rotundata rhizome and exposed boring bivalves anterior and its shell valve.

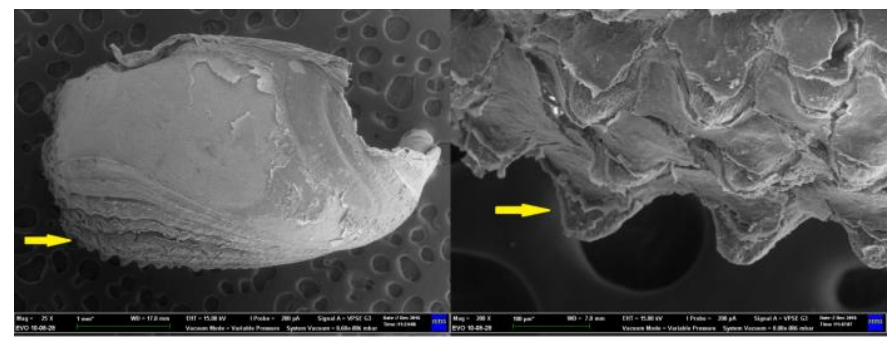

Figure 6. Shell valve under Scanning Electron Microscope 60X (left) and 200X (right). Photos reveal rows of the toothed ridge (indicated with a yellow arrow), which served as a tool to bore and shred plant material for ingestion.

\section{Effects on seagrass health}

The average growth rate of an Enhalus shoot infested with Zachsia was recorded at $0.220 \pm 0.038 \mathrm{~cm}^{-1} \mathrm{day}^{-1}$ compared to $0.438 \pm 0.071 \mathrm{~cm} \mathrm{day}^{-1}$ for un-infested shoots but sharing the same infested rhizome. Infested shoot and rhizome showed the lowest growth rate compared to healthy seagrass $0.738 \pm$ $0.036 \mathrm{~cm} \mathrm{day}^{-1}$ (Table 2). The t-test shows that growth rate of infested shoot $(n=5)$ is significantly different $(\mathrm{p}<0.05)$ from uninfected shoot $(\mathrm{n}=99, \mathrm{t}=-3.2012, \mathrm{p}=0.0018248)$, and same is true for infested rhizome $(n=13)$ from uninfected rhizome $(n=91, t=-3.9395, p<0.05)$. The leaves of the infested shoots gradually turned yellowish brown and detached even with a gentle touch. Development of a bulbous mass, with smooth surface features, was also noticeable at the base of the detached leaf. The mass was easily detachable from shoot's meristem and rhizome node.
Table 2. Growth rate measured in 16 Enhalus shoots (26 June - 17 July 2016) in seagrass husbandry tank.

\begin{tabular}{lccc}
\hline & \multicolumn{2}{c}{ Infested rhizome } & $\begin{array}{c}\text { Un-infested } \\
\text { rhizome }\end{array}$ \\
\cline { 2 - 4 } & $\begin{array}{c}\text { Infested } \\
\text { shoot }\end{array}$ & $\begin{array}{c}\text { Un-infested } \\
\text { shoot }\end{array}$ & $\begin{array}{c}\text { Un-infested } \\
\text { shoot }\end{array}$ \\
\hline Total shoot & 1 & 1 & 14 \\
$\mathrm{~N}$ & 5 & 8 & 91 \\
Growth rate (cm & 0.220 & 0.438 & 0.738 \\
day-1) & & 0.071 & 0.036 \\
Standard Error (SD) & 0.038 & & \\
\hline
\end{tabular}

\section{Discussion}

There is a paucity of information on the genus Zachsia due to the rare occurrence of this species living inside seagrass rhizome and buried in the sediment. Only one1 species had been described, Zachsia zenkewitschi and scientific data was published in German, Korean, Japan and Russian language journals, which makes it difficult to be widely used. The study, while limited in its extent, found that boring bivalves are indeed prevalent across the tropical mixed bed seagrass meadows of Gaya Island, dominated by E. acoroides and $C$. rotundata. The finding also suggests that Zaschia is likely to have a broader regional and climatic niche across the globe than the previous observations implied. This is consistent with the observations made by Turner and Yakovlev (1983) and Shipway et al. (2016), and with the evidence from empty calcareous linings in two Enhalus rhizomes in Trang Province, Thailand in December 2016 (Akkalak Chattanachort, personal communication).

Some differences were discernible in pallet morphology in the specimens observed in this study and also recent descriptions of $Z$. zenkewitschi by Shipway et al., (2016) and Haga (2006). The pallets observed by us were relatively narrower and longer, suggesting this to be the record of a new species (Turner, 1966; Turner and Yakovlev,1983) compared to short, broader and diamond shape of Z. zenkewitschi. Unlike other members which have unique pallet shape, close similarity between our specimens with $Z$. zenkewitschi posed a challenge in identification as there were no keys to differentiate them. Further investigation into the shape and ratio length-width can be considered, which may serve as an additional key feature in identification in the future. Molecular study of the specimens confirmed the status of this species and will be published in a future publication.

Zachsia is the sole member of the Teredinidae family that displays male dwarfism. This feature is common in parasitic and commensal species and has been reported to occur in at least 13 classes and 8 phyla (Kliman, 2016). However, based on the two observations, we found potential exceptions to this strategy. Two similar sized calcareous tubes containing living specimens occupied the same Enhalus rhizome (Figure 3) but the advantages of this phenomenon are unclear. It could be a species-specific behaviour or specific to the type of host could not be established. In other words, a larger rhizome had sufficient 
room and resources for the development of two adult females. Either way, it is possible that both larvae did not detect any female chemical attractant as proposed by Shipway et al. (2016) and started boring into the rhizome to metamorphose into a female at the same time.

\section{Seagrass parasitism}

Boring invertebrates included few species of polychaete, isopods, and nematodes. They bore into old seagrass sheath and some into rhizome. Boring activity by polychaetes (Lysidice ninetta, L. collaris, Nematonereis unicornis) and crustacean isopod Limnoria tuberculate did not affect seagrass Posidonia oceanica in its growth dynamic and production (Guidetti, 2000). These boring invertebrate rarely graze on living plant tissues. Instead, they ingest decayed plant biomass and recycle the nutrients back to the system, which benefits the seagrass. Gambi et al. (2003) noticed that the isopod borer (genus Limnoria) severely affected the seagrass because it burrows near or in the meristem region of the plant. Investigations on the seagrass borer species are relatively limited, and thus it is difficult to characterize their ecological function as a detritivore or herbivore or to comment on their parasitic mode of living.

The existence of Zachsia inside the living rhizosphere appears to be a means of helping in its reproduction (Yakovlev et al., 1998; Haga 2006; Shipway et al., 2016), growth (Kiyashko, 1986) and apparently successful dispersion across the meadow. Infestation of up to $11 \%$ in seagrass meadows in Gaya Island seems to be a significant dispersal. Although detailed investigations need to be carried out, preliminary observations have shown a reduction in seagrass biological fitness, in terms of growth, and death of all infested shoots after a period of time. There was as much as $70 \%$ decline in the shoot growth rate and no apparent regeneration of the infected rhizome, only the remnants of a calcareous lining was conspicuous by its presence.

The decline in growth could be due to an interruption in nutrient uptake from the sediment, or other factors as suggested by Kiyashko (1986). Bulb mass formation at leaf meristem point, adjacent to emerging calcareous tube severe all the tissue connection between above and below the ground biomass. Disruption of nutrient supply, mainly nitrogen and phosphorus, from the rhizome to leaf (Terrados et al., 1999) would hold back the plant photosynthesis which caused a reduction of about $70 \%$ in the growth rate and resulted in the death of the plant.

Furthermore, whether or not the suggested parasitic mode of Zachsia is obligatory is difficult to confirm because there is evidence that it is able to survive after 3 months of starvation (Turner et al., 1983). This raises the possibility of Zachsia entering a dormant phase until conditions are favourable. Likewise, boring bivalve in this study does not reflect such condition. Further investigation of its biological and ecological interactions will help in better understanding the impact of Zachsia on the seagrass ecosystem.

\section{Conclusion}

This study established the presence of a new species of Zachsia in the tropical seagrasses, E. acoroides and $C$. rotundata, in the region of Kota Kinabalu. This species could have a wider distribution across the tropical regions. Shoot occupancy for both seagrass species was around $12 \%$ and $1 \%$, respectively and this suggested a parasitic mode of life of the bivalve. Impacts of this infestation on seagrass growth, productivity and mortality are unclear. Nevertheless, the observations indicated that the relatively large infestation associated with E. acoroides could have implications since this seagrass is slow growing and has a smaller number of shoots. Either way, parasitic significance highlights the limitations of current conceptual models of seagrass meadow growth and mortality. This must be taken into precaution in seagrass transplantation to prevent any introduction of parasites and to ensure a higher success of the restoration effort.

\section{Acknowledgements}

This work was supported by Fundamental Research Grant Scheme (Grant: FRGS0424-SG-1/2015). Research facilities were provided by the Marine Ecology Research Centre (MERC). Special thanks are due to Datuk Robert Tan and Alvin Wong, owner and project manager of MERC, respectively for all the possible cooperation. Rueben Shipway assisted in the identification of the seagrass boring bivalve.

\section{References}

Bujang, J. S., Zakaria, M. H. \& Arshad, A. (2006). Distribution and significance of seagrass ecosystems in Malaysia. Aquatic Ecosystem Health \& Management 9(2), 203-214.

Burkholder, D. A., Reithaus, M. R., Fourqureen, J.W. et al. (2013). Patterns of top-down control in a seagrass ecosystem: Could a roving apex predator induce a behaviour-mediated trophic cascade?' Journal of Animal Ecology 82(6), 1192-1202.

Cookson, L.J., \& Lorenti, M. (2001). A new species of Limnoriid seagrass borer (Isopoda) from the Mediterranean. Crustaceana 74(4), 339-346.

Duarte, C. M., Merino, M., Agawin, N.S.R. et al. (1998). Root production and belowground seagrass biomass, Marine Ecology Progress Series 171, 97-108.

Duarte, C. M. (2002).The future of seagrass meadows. Environmental Conservation. 29(2), 192-206.

Duarte, C. M., Kennedy, H., Marba, N. et al. (2013). Assessing the capacity of seagrass meadows for carbon burial: Current limitations and future strategies. Ocean and Coastal Management 83, 32-38.

Gambi, M. C., Van Tussenbroek, B. I. \& Brearley, A. (2003). Mesofaunal borers in seagrasses: World-wide occurrence and a new record of boring polychaetes in the Mexican Caribbean. Aquatic Botany 76, 65-77.

Guidetti, O., Bussotti, M., Gambi, M.C. et al. (1997). Invertebrate borers in Posidonia oceanica scales: relationship between their distribution and lepidochronological parameters. Aquatic Botany 58(2), 151-164.

Guidetti, P. (2000). Invertebrate borers in the Mediterranean sea grass Posidonia oceanica: Biological impact and ecological implications. Journal of the Marine Biological Association of the United Kingdom 80(4), 725730 . 
Haga, T. (2006). The rhizome-boring shipworm Zachsia zenkewitschi (Bivalvia: Teredinidae) in drifted eelgrass. Venus 65(3), 263-266.

Kliman, R.M., 2016. Encyclopedia of Evolutionary Biology. Acedemic Press

Orth, R., Harwell, M., Bailey, E. et al. (2000). A review of issues in seagrass seed dormancy and germination: implications for conservation and restoration. Marine Ecology Progress Series 200, 277-288.

Kiyashko, S. I. (1986).The diet of Zachsia zenkewitschi (Bivalve: Teredinidae), investigated by the 13C:12C Method. Asian Marine Biology 3, 139-143.

Marvier, M. A. (1998). Parasite Impacts on host communities : Plant parasitism in a California Coastal Prairie. Ecology 79(8), 2616-2623.

Shipway, J. R., Connor, R.O., Stein, D. et al. (2016). Zachsia zenkewitschi (Teredinidae), a rare and unusual seagrass boring bivalve revisited and redescribed. PLoS ONE 11(5), 1-12. doi: 10.1371/journal.pone.0155269.

Short, F. T., Carruthers, T., Dennison, W. et al. (2007). Global seagrass distribution and diversity: A bioregional model. Journal of Experimental Marine Biology and Ecology 350, 3-20.

Terrados, J., Borum, J., Duarte, C.M. et al. (1999). Nutrient and mass allocation of South-east Asian seagrasses. Aquatic Botany 63(3-4), 203217.

Thrower, L. B., \& Chan, Y.S. (1980). Gau sun: A cultivated host-parasite combination from China. Economic Botany 34(1), 20-26.

Turner, R. D. (1966). A survey and illustrated catalogue of the Teredinidae (Mollusca: Bivalve). Museum of Comparative Zoology, Harvard University, Cambridge. Mass. 265pp

Turner, R. D., \& Yakovlev, Y. (1983). Dwarf males in the Teredinidae (Bivalvia, Pholadacea). Science 219(3), 1077-1078.

Turner, R. D., Yakovlev, Y. M. \& Karaseva, E. M. (1983). Some aspects of the life-history of a bivalve mollusk Zachsia-zenkewitschi. Biologiya MoryaMarine Biology 5(5), 257-264.

Voight, J. R. (2015). Xylotrophic bivalves: Aspects of their biology and the impacts of humans. Journal of Molluscan Studies 81(2), 175-186.

Wondafrash, M., Van Dam, N. M. \& Tytgat, T. O. G. (2013). Plant systemic induced responses mediate interactions between root parasitic nematodes and aboveground herbivorous insects. Frontiers in plant science 4(April), 87.

Xu, F. and Zhang, J. (2012). Characteristics of bivalve diversity in typical habitats of China seas. Biodiversity Science 19(6), 716-722.

Yakovlev, Y. M., Drozdov, A. L., \& Ferraguti, M. (1998). Peculiarities of reproduction and gamete structure of shipworm Zachsia zenkewitschi (Bivalvia: Teredinidae). Korean J. Malacology 14(1), 1-8. 